\title{
Factors influencing locomotor capacity of hemiparetic post-stroke patients
}

\author{
Antonio Vinicius-Soares ${ }^{1 *}$, Carla T. Juvêncio-de-Oliveira ${ }^{2}$, Fernando L. Fischer-Eichinger ${ }^{3}$, and \\ Fabrício Noveletto 4 \\ ${ }^{1}$ Post-graduate Program in Health and the Environment, University of the Region of Joinville - UNIVILLE and IELUSC College; ${ }^{2}$ Department of \\ Physical Therapy, Guilherme Guimbala College; ${ }^{3}$ Department of Physical Therapy, Guilherme Guimbala College and University of the Joinville Region \\ - UNIVILLE; ${ }^{4}$ Department of Electrical Engineering, Santa Catarina State University - UDESC and Guilherme Guimbala College, Santa Catarina. \\ Joinville, Brazil
}

\begin{abstract}
Background: The locomotor recovery is the most desired goal by patients and clinicians. Measurement of gait speed (GS) provides a fast and reliable clinical parameter for this function. The aim of this study was to verify the relationship between GS and different variables, such as age, injury time, body composition, functional mobility, spasticity, motor recovery, and muscle strength. Material and methods: The study included 24 patients with average age 57.6 ( \pm 10.5) years post-stroke hemiparetics. Two groups of patients were formed, those who walked with GS higher than $0.80 \mathrm{~m} / \mathrm{s}(n=8)$ and another group with GS lower than $0.80 \mathrm{~m} / \mathrm{s}(n=16)$. They were evaluated by the GS test, Timed Up and Go Test (TUGT), Fugl-Meyer scale (FMS), Modified Ashworth Scale (MAS), bilateral dynamometry of extensors and flexors knee, and determination of body mass index (BMI). Results: In the correlation analysis between GS and other variables, in the group with GS higher than $0.80 \mathrm{~m} / \mathrm{s}$, there was a significant correlation with TUGT $(r=-0.77)$ and strength tests $(r \geq 0.80)$. In the group with $G S<0.80 \mathrm{~m} / \mathrm{s}$, there was a moderate to strong correlation with TUGT ( $r=-0.87)$, FMS $(r=0.74)$, MAS $(r=-0.62)$, and quadriceps femoris muscle strength in paretic side $(r=0.55)$. In both groups, no significant correlations were found with age, stroke time, and BMI. Conclusion: The study indicates that the combination of an important motor deficit expressed by greater strength asymmetry between the paretic and non-paretic sides, and a greater degree of spasticity results in worse performance in the GS.
\end{abstract}

Key words: Gait. Hemiparesis. Stroke.

\section{Factores que influyen en la capacidad locomotora de los pacientes hemiparéticos por accidente cerebrovascular}

\section{Resumen}

Antecedentes: La recuperación locomotora es el objetivo más deseado por los pacientes y los clínicos. La medición de la velocidad de la marcha (VM) proporciona un parámetro clínico rápido y fiable para esta función. El objetivo de este estudio fue verificar la relación entre VM y diferentes variables, como la edad, el tiempo de lesión, la composición corporal, la mo-

\section{Correspondence:}

*Antonio Vinicius-Soares

Date of reception: $21-08-2019$ Date of acceptance:05-02-2020 Santa Catarina, Joinville, Brazil E-mail: antonio.vinicius@univille.br (http://creativecommons.org/licenses/by-nc-nd/4.0/). 
vilidad funcional, la espasticidad, la recuperación motora y la fuerza muscular. Material y métodos: El estudio incluyó a 24 pacientes con una edad promedio de $57.6( \pm 10.5)$ años después de un accidente cerebrovascular. Se formaron dos grupos de pacientes, los que caminaron con VM superior a $0.80 \mathrm{~m} / \mathrm{s}(n=8)$, y otro grupo con VM inferior a $0.80 \mathrm{~m} / \mathrm{s}(n=16)$. Fueron evaluados por la prueba de VM, la prueba Timed Up and Go (TUG), la escala de Fugl-Meyer (EFM), la escala de Ashworth modificada (EAM), la dinamometría bilateral de extensores y flexores de rodilla, y la determinación del índice de masa corporal (IMC). Resultados: En el análisis de correlación entre la VM y otras variables, en el grupo con VM superior a $0.80 \mathrm{~m} / \mathrm{s}$ hubo una correlación significativa con la prueba TUG $(r=-0.77)$ y la pruebas de fuerza $(r \geq 0.80)$. En el grupo con VM inferior a $0.80 \mathrm{~m} / \mathrm{s}$ hubo una correlación de moderada a fuerte con la prueba TUG $(r=-0.87)$, la EFM ( $r$ : 0.74), la EAM ( $r=-0.62)$ y la fuerza muscular del cuádriceps femoral en el lado parético $(r=0.55)$. En ambos grupos no se encontraron correlaciones significativas con la edad, el tiempo desde el accidente cerebrovascular y el IMC. Conclusión: El estudio indica que la combinación de un importante déficit motor, expresado por una mayor asimetría de fuerza entre los lados parético y no parético, y un mayor grado de espasticidad resulta en un peor desempeño en la VM.

Palabras clave: Marcha. Hemiparesia. Accidente cerebrovascular.

\section{Introduction}

Stroke is one of the main causes of hospitalizations and mortality in Brazil and worldwide. In general, it causes some kind of deficiency, either partial or complete $^{1}$. The motor deficits resulting from this disease cause muscle weakness, reduced mobility, and limited ability to perform functional tasks and affect about $40 \%$ of people who do not walk independently in the community ${ }^{2}$.

It is understood that the non-paretic lower limb has a higher proportion of body weight that results in the oscillation of the orthostatic posture, characterizing an asymmetrical profile in weight transfer and greater oscillations on the paretic side than the non-paretic side, hindering the ability to walk. These changes in gait cause postural instability, limit gait capacity, increasing the risk of falls, and compromising the functional independence of these patients ${ }^{3}$.

Recovery from walking is the most desired goal for patients and clinicians. For Fritz and Lusardi ${ }^{4}$, gait speed (GS) is the "sixth vital sign." As a basic clinical parameter, this function is evaluated by the GS test (GST), which is easy to apply, fast, and reliable. In general, the patients with the best performance in GS $(>0.80 \mathrm{~m} / \mathrm{s})$ are those who present with the lowest deficits, the best functional performance, and greater independence in the activities of daily living (ADLs), being usually independent ambulators in the community. On the other hand, those with poorer performance in GS $(<0.80 \mathrm{~m} / \mathrm{s})$ are the most neurologically compromised patients, who present higher functional dependence, higher risk of falls, and hospitalization, and, in general, are home ambulators, especially those with GS $<0.40 \mathrm{~m} / \mathrm{s}^{5,6}$.

The aim of this research was to verify the relationship between GS and different variables, such as age, injury time, body composition, muscle strength, spasticity, and functional mobility in hemiparetic stroke patients.

\section{Methodology}

The study was descriptive correlational'. It was performed at the Center for Neurorehabilitation at Guilherme Guimbala College, in Joinville, Santa Catarina, Brazil. This study was approved by the Ethics Committee for Research Involving Human Beings (number 1.671.505). The participants were informed about the objectives and procedures of the study and signed the free and informed consent form.

\section{Study participants}

Consecutive volunteers of both genders aged 35 years and older, with a clinically stable history of stroke, in the subacute (between 3 and 6 months after the event) or chronic phases (more of 6 months after stroke episode) participated in the study. The patients were informed about the evaluation procedures that would be performed in the application of the study and were then invited to participate in the study.

As requisites for participation in the study, the inclusion and exclusion criteria described below were established.

\section{Inclusion criteria}

Hemiparetic stroke patients, clinically stable and in the subacute or chronic phases; age range from 35 years; be in agreement and show interest in participating in the project from start to finish; and then, they signed the free and informed consent form. 


\section{Exclusion criteria}

Patients with hemiparesis due to other pathologies than stroke as well as hemiplegic patients; severe visual and/or auditory impairment; non-cooperative patients and/or patients with severe cognitive deficit assessed by means of the Mini-Mental State Examination with the cutoff points proposed by Bertolucci et al. ${ }^{8}$; and patients who could not walk independently, even if using walking aid devices such as crutch, cane, or walker were excluded from the study.

\section{Measuring instruments and procedures}

\section{REGISTRATION FORM}

This form included patient identification data and other general information (name, date of birth, address, telephone number, laterality, use of orthoses, and/or walking aids), sociodemographic data (gender, marital status, ethnicity, level of education, professional status, and profession), as well as clinical information (if the patient had more than one stroke, stroke type and time, main complaint, medications in use, adjuvant treatments, dysfunctions and/or associated pathologies, smoking, alcohol consumption, and family history of the disease) and anthropometric information (height, body mass, and body mass index [BMI]).

\section{Digital Anthropometric Scale and Stadiometer}

To measure body mass, a digital Omron ${ }^{\circledR}$ scale, model HBF-514C, BR, duly calibrated, was used, and the unit of measurement was recorded in kilograms $(\mathrm{kg})$. Height was measured by means of a Sanny ${ }^{\circledR}$ stadiometer, model ES2020, manufactured by American Medical do Brasil Ltda., BR. This instrument has an accuracy of $0.1 \mathrm{~mL}$, and the measurement was recorded in meters $(\mathrm{m})$.

The BMI was obtained by means of the ratio between body mass $(\mathrm{kg})$ and height $(\mathrm{m})$ squared. The classification was performed according to the following cutoff points proposed by the World Health Organization (WHO): low weight $\left(<18.50 \mathrm{~kg} / \mathrm{m}^{2}\right)$; normal weight (18.50$\left.24.99 \mathrm{~kg} / \mathrm{m}^{2}\right)$; overweight $\left(25.00-29.99 \mathrm{~kg} / \mathrm{m}^{2}\right)$; Grade I obesity (30.00-34.99 kg/m²); Grade II obesity (35.00$\left.39.99 \mathrm{~kg} / \mathrm{m}^{2}\right)$; and Grade III obesity $\left(\geq 40.0 \mathrm{~kg} / \mathrm{m}^{2}\right)^{9}$.

\section{Fugl-MeYer Scale (FMS)}

The FMS was used to measure the level of motor impairment. It is noteworthy that in the present study only, the section destined to the motor evaluation of the lower limb was used, which includes the analysis of reflex activity, synergic muscle action in flexion and extension, and the movements with and without synergy. The patients were classified according to the degree of motor impairment in severe (0-7), strong $(>7-14)$, moderate $(>14-21)$, and light $(>21-28)^{10}$.

\section{Modified Ashworth Scale (MAS)}

The MAS was used to evaluate the degree of spasticity. It should be noted that only the spasticity of the quadriceps femoris muscle was evaluated.

This scale grades the spasticity in six levels: 0 - there is no increase in muscle tone; 1 - slight increase in muscle tone, manifested by a slight capture and release, or by minimal resistance at the end of the range of motion, when the affected part is moved in flexion or extension; 2 - slight increase in muscle tone, manifested by a slight capture followed by minimal resistance throughout the rest (less than half) of the range of motion; 3 - more accentuated increase in muscle tone during most of the range of motion, but the affected parts are easily moved; 4 - considerable muscle tone increased, difficult passive movement; and 5 - rigid affected parts, in flexion or extension ${ }^{11}$.

\section{TIMEd Up and Go TeSt (TUGT)}

The TUGT was used to evaluate functional mobility ${ }^{12,13}$. The test requires the individual to stand up from a standardized chair with support, walk $3 \mathrm{~m}$ in a straight line on the floor, return to the chair, sitting in the initial position, and the time to perform this task is recorded in seconds. In addition to being a quick and easy to apply test, it has been widely used in individuals with stroke ${ }^{14-17}$, as it has proven to be a valid and highly reliable instrument in the evaluation of this population.

At present, the TUGT is considered the best predictor of participation of individuals with stroke in the ADLs ${ }^{18}$. The instrument demonstrates good intraexaminer (ICC 0.95) and interexaminer reliability (ICC 0.98$)^{19}$.

\section{GST}

GS is considered a fast, practical, and reliable measure. It is related to functional mobility, level of independence, risk of falls, and hospitalization ${ }^{4,6}$.

The patients were divided into two groups. The first group had the best performance in GST (>0.80 m/s). In 


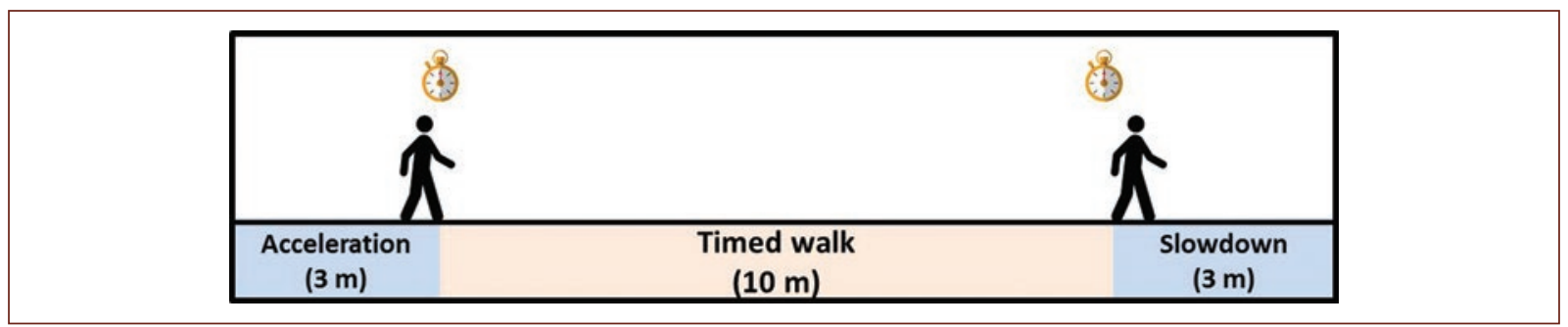

Figure 1. Method used for the gait speed test (adapted of Fritz e Lusardi').

general, these patients are community ambulators and are less neurologically compromised. The second group, with the worst performance in GST $(<0.80 \mathrm{~m} / \mathrm{s})$, is patients who present greater neurological impairment, present worse functional performance, risk of falls, and hospitalization, and, in general, are home walkers ${ }^{4,6}$.

During the GST, the patients were instructed to perform the test as soon as possible on a $10 \mathrm{~m}$ path for timing (Fig. 1). To eliminate the effects of acceleration and deceleration in the test, a distance of $3 \mathrm{~m}$ was added at the beginning and end of the route. The patient started walking and, after a distance of $3 \mathrm{~m}$, the stopwatch was activated. The time count ended at the 10 $\mathrm{m}$ marker, leaving another $3 \mathrm{~m}$ left for the patient's deceleration. Therefore, the unit of measurement used for GS was meters per second $(\mathrm{m} / \mathrm{s})$.

\section{Dynamometry}

To measure the strength of the extensor (EM) and flexor muscles (FM) knee, a Bonnet chair was prepared and adapted with a load cell, which is attached to the chair, allowing bilateral evaluation of the strength of the muscle groups mentioned above. A load cell of the IWM $^{\circledR}$ brand, model GL-100 China, was used, which acts through the compression mechanism, with a capacity of $60 \mathrm{~kg}$, properly calibrated. This cell has a division of $0.1 \mathrm{~kg}$ and sensitivity of $2.0 \mathrm{mV} / \mathrm{V}$. Its excitation voltage is from 6 to $10 \mathrm{~V}$.

The positioning of the patient and the equipment was different for each muscle group. For EM, the following positioning was adopted: patient seated in the chair, with the trunk supported on the backrest, with legs hanging, hip at $110^{\circ}$ flexion in relation to the trunk and knees flexed at $90^{\circ 20-23}$; for this muscle group, the equipment (sensor with the load cell) was positioned at the level of the distal third of the leg (just above the malleolar region), on the anterior face. For FM, it was used: patient seated in the chair, with the trunk supported on the backrest, hip at $110^{\circ}$ flexion in relation to the trunk and knees flexed at $60^{\circ 24}$; for this muscle group, the equipment was also positioned at the level of the distal third of the leg, however, on the posterior face. Figure 2 illustrates the positioning of the patient and the sensor with the load cell during the procedures.

Three bilateral measurements of each muscle group were performed in maximum voluntary isometric contraction during a period of $5 \mathrm{~s}^{21,25}$, with an interval of $60 \mathrm{~s}$ between each measurement. It is noteworthy that the measurements were taken on alternate days and, as a reference, the arithmetic mean resulting from the three evaluations was recorded. The patient was instructed to perform as much force as possible from a green signal projected on the screen, which indicated the beginning of the test, and this strength should be maintained until the disappearance of the green color, indicating the end of the test.

\section{Data analysis}

Data tabulation and analysis were performed using GraphPad Prism $6^{\circledR}$ software, determining minimum, maximum, mean, and standard deviation values. To verify the relationship between the study variables (GS vs. other variables), we used Pearson's correlation test for parametric variables (BMI, TUGT, and muscle strength measurements through dynamometry) and Spearman's correlation test for non-parametric data (FMS and MAS). The significance level of 95\% $(p<0.05)$ was considered.

\section{Results}

Twenty-four patients participated in the study, 12 men and 12 women with post-stroke hemiparesis. All patients suffered an ischemic stroke confirmed by examination of images such as computed tomography and/or magnetic resonance imaging. Two groups of patients were formed, those who walked with GS higher than $0.80 \mathrm{~m} / \mathrm{s}$ and another with GS lower than $0.80 \mathrm{~m} / \mathrm{s}$. 


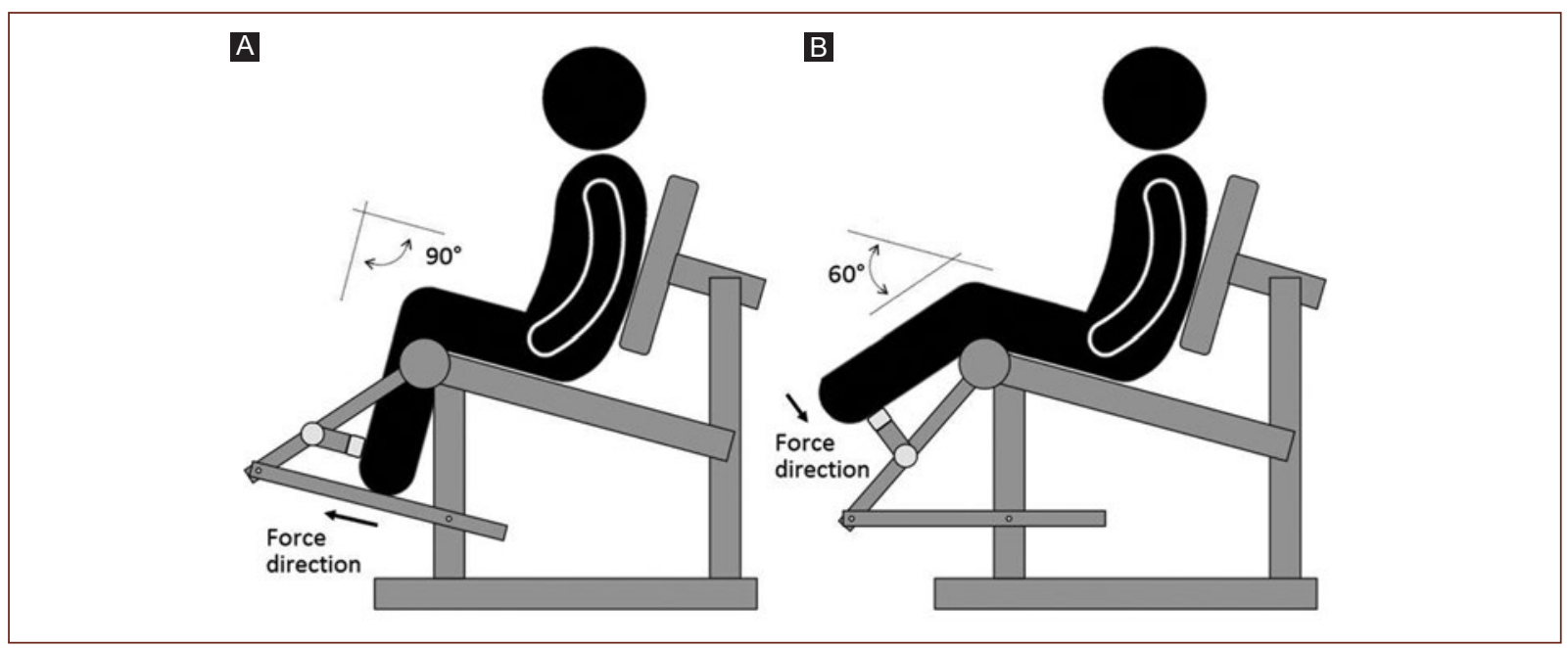

Figure 2. Positioning of the patient and the load cell for the evaluation of the muscle groups addressed in the study. A: extensors muscles dynamometry. B: flexors muscles dynamometry.

Table 1. Descriptive statistics of the group with good performance in gait speed test $(>0.80 \mathrm{~m} / \mathrm{s})$

\begin{tabular}{|l|c|c|c|c|c|c|c|c|c|c|c|}
\hline & Age & ST & BMI & TUGT & GST & FMS & MAS & ESp & ESnp & FSp & FSnp \\
\hline M & 59.3 & 23.3 & 27.4 & 12.7 & 1.06 & 25.6 & 0.50 & 17.6 & 24.0 & 7.9 & 12.0 \\
\hline DP & 10.3 & 35.7 & 5.68 & 2.71 & 0.27 & 3.0 & 0.76 & 10.2 & 7.9 & 5.9 & 6.4 \\
\hline Minimum & 46.0 & 4.00 & 17.6 & 8.62 & 0.80 & 19.0 & 0.0 & 7.30 & 13.3 & 2.8 & 5.4 \\
\hline Maximum & 70.0 & 108 & 37.7 & 18.4 & 1.64 & 28.0 & 2.00 & 35.3 & 36.2 & 18.3 & 23.9 \\
\hline
\end{tabular}

ST: stroke time (months); BMI: body mass index $\left(\mathrm{kg} / \mathrm{m}^{2}\right)$, TUGT: timed up and go test (time in s); GST: gait speed test in $10 \mathrm{~m}$ (m/s); FMS: Fugl-Meyer scale - lower limb section (0-28); MAS: Modified Ashworth Scale (0-5); ESp: extensors muscle strength paretic side (kgf); ESnp: extensors muscle strength non-paretic side (kgf); FSp: flexors muscle strength paretic side (kgf); FSnp: flexors muscle strength non-paretic side (kgf).

Patients are seen at a physical therapy service twice a week regularly.

Next, data from the statistical analysis of the group with the best performance in GST $(>0.80 \mathrm{~m} / \mathrm{s}$ ) are presented. Tables 1 and 2 show descriptive statistics and correlation analysis data. Eight patients participated in this group, five men and three women.

Then, data from the statistical analysis of patients who wander with GST $<0.80 \mathrm{~m} / \mathrm{s}$ (16 patients, 7 men and 9 women) are presented. Tables 3 and 4 present the descriptive statistics and correlation analysis data.

The groups when stratified based on GST were not different in terms of epidemiological and general clinical aspects, such as age, post-stroke injury time, and BMI. However, when compared to the other variables between the groups such as GST, TUGT, FMS, and MAS, it is observed that there is a significant difference between them. As for muscle strength tests, no significant difference was observed, although on the paretic side, the group with the worst performance in GS tests had a deficit of $28.4 \%$ in extensors muscles and $38.0 \%$ in flexors muscles lower than the group with the best performance. This may have an important clinical repercussion, as indicated in correlation tests involving this variable.

\section{Discussion}

Walking in hemiparetic patients after stroke is described as uncoordinated, arrhythmic, and unbalanced ${ }^{5,26,27}$. The GS is a clinical and biomechanical parameter that quickly, easily, and reliably translates performance in this primary function. In fact, there is a relationship between the performance in GST and the level of functional independence, risk of falls, and hospitalization of these patients ${ }^{5,6}$.

In individuals affected by stroke, although GS is a determining factor of functional capacity, other variables may be associated with functional deficit, such as anthropometric characteristics ${ }^{28}$. In our study, the correlation between BMI and GS was weak and not significant for both groups. Similar results were found 
Table 2. Correlation analysis of the group with good performance (gait speed test $>0.80 \mathrm{~m} / \mathrm{s}$ )

\begin{tabular}{|c|c|c|c|c|c|c|c|c|c|c|}
\hline & Age & ST & BMI & TUGT & FMS & MAS & ESp & ESnp & FSp & FSnp \\
\hline$r$ & 0.66 & -0.37 & 0.15 & -0.77 & 0.70 & -0.54 & 0.87 & 0.80 & 0.85 & 0.85 \\
\hline$p$ & 0.077 & 0.370 & 0.718 & 0.026 & 0.061 & 0.060 & 0.005 & 0.018 & 0.007 & 0.008 \\
\hline
\end{tabular}

ST: Stroke time (months); BMI: body mass index ( $\left.\mathrm{kg} / \mathrm{m}^{2}\right)$; TUGT: timed up and go test (time in s); FMS: Fugl-Meyer scale - lower limb section (0-28); MAS: Modified Ashworth Scale (0-5); ESp: Extensors muscle strength paretic side (kgf); ESnp: Extensors muscle strength non-paretic side (kgf); FSp: flexors muscle strength paretic side (kgf); FSnp: flexors muscle strength non-paretic side (kgf).

Table 3. Descriptive statistics of the group with worst performance (gait speed test $<0.80 \mathrm{~m} / \mathrm{s}$ )

\begin{tabular}{|l|c|c|c|c|c|c|c|c|c|c|c|}
\hline & Age & ST & BMI & TUGT & GST & FMS & MAS & ESp & ESnp & FSp & FSnp \\
\hline M & 56.8 & 20.1 & 28.9 & 35.1 & 0.38 & 19.5 & 1.9 & 12.6 & 23.3 & 4.9 & 11.7 \\
\hline DP & 10.8 & 22.5 & 8.34 & 20.7 & 0.2 & 4.9 & 1.7 & 7.3 & 8.0 & 3.0 & 4.6 \\
\hline Minimum & 37.0 & 3.0 & 18.4 & 14.2 & 0.1 & 11.0 & 0.0 & 3.8 & 11.4 & 0.8 & 6.4 \\
\hline Maximum & 79.0 & 96.0 & 44.8 & 88.5 & 0.7 & 27.0 & 5.0 & 28.1 & 39.6 & 12.8 & 21.1 \\
\hline
\end{tabular}

ST: stroke time (months); BMI: body mass index (kg/m²); TUGT: timed up and go test (time in s); GST: gait speed test in $10 \mathrm{~m}$ (m/s); FMS: Fugl-Meyer scale - lower limb section (0-28); MAS: Modified Ashworth Scale (0-5); ESp: extensors muscle strength paretic side (kgf); ESnp: extensors muscle strength non-paretic side (kgf); FSp: flexors muscle strength paretic side (kgf): FSnp: flexors muscle strength non-paretic side (kgf).

Table 4. Correlation analysis of the group with worst performance (GST $<0.80 \mathrm{~m} / \mathrm{s}$ )

\begin{tabular}{|c|c|c|c|c|c|c|c|c|c|c|}
\hline & Age & ST & BMI & TUGT & FMS & MAS & ESp & ESnp & FSp & FSnp \\
\hline$r$ & 0.27 & -0.26 & -0.03 & -0.87 & 0.69 & -0.61 & 0.55 & 0.30 & 0.39 & 0.13 \\
\hline$p$ & 0.316 & 0.335 & 0.928 & 0.000 & 0.004 & 0.010 & 0.026 & 0.257 & 0.135 & 0.637 \\
\hline
\end{tabular}

ST: stroke time (months): BMI: body mass index ( $\left.\mathrm{kg} / \mathrm{m}^{2}\right)$ : TUGT: timed up and go test (time in s); FMS: Fugl-Meyer scale - lower limb section (0-28); MAS: Modified Ashworth Scale (0-5); ESp: Extensors muscle strength paretic side (kgf); ESnp: Extensors muscle strength non-paretic side (kgf); FSp: Flexors muscle strength paretic side (kgf); FSnp: flexors muscle strength non-paretic side (kgf).

in a study by Sheffler et al. ${ }^{29}$, where the influence of body mass on hemiparetic gait was evaluated. Although overweight may negatively affect post-stroke gait, the authors find no association between BMI and specific spatial-temporal parameters, including GS, cadence, double support time, or step length when measured over short distances.

Muscle strength and endurance seem to play a special role for good performance in this function, and this directly affects the functional capacity ${ }^{6}$. Although the paretic side is the most affected in relation to muscle strength, the non-paretic side may also show reduced strength. In individuals affected by stroke, the strength deficits range from $17 \%$ to $40 \%$ on the paretic side and from $5 \%$ to $40 \%$ on the non-paretic side. It is worth noting that this asymmetry of strength can also occur in healthy people, but in a smaller proportion (up to $10 \%)^{27}$.

In a study conducted by Hyun et al..$^{30}$, the strength of the knee extensors and the dynamic balance was evaluated as predictors of walking in hemiparetic patients due to stroke in the acute phase. Fifty-three patients participated in the study, who were stratified in domestic ambulators (GST $<0.4 \mathrm{~m} / \mathrm{s}$ ) and community ambulators (GST $>0.4 \mathrm{~m} / \mathrm{s}$ ). The function of balance and functional mobility was evaluated using the Berg Balance Scale and the TUGT, respectively. The strength of the extensors and flexors knee was measured with an isokinetic dynamometer. The results found in the study indicate that the balance and strength of the knee extensors are the strongest predictors for the gait function of patients. However, the authors point out that the results may vary according to the severity of the gait. These findings corroborate those obtained in our study, where in the group with the best performance in GST $(>0.8 \mathrm{~m} / \mathrm{s})$, there was a strong and significant correlation $(r \geq 0.80)$ of both muscle groups, flexors and extensors knee on the paretic side. Moreover, for the other group, with poorer performance in GST $(<0.8 \mathrm{~m} / \mathrm{s})$, the extensors knee strength also showed significant correlation.

Still regarding the evaluation of muscle strength, it is important to comment on the asymmetry found between the paretic and non-paretic sides. In the group with the 
best performance in GST, there was less asymmetry, $26.7 \%$ in the extensors muscles knee and $34.2 \%$ lower in the flexors muscles side than in the non-paretic side. In the group with the worst performance in GST, this asymmetry is remarkable. An asymmetry of $45.9 \%$ was found in the extensors muscles and $58.1 \%$ in the flexors muscles in relation to the non-paretic side. In some cases, this asymmetry is even higher than that observed in the literature ${ }^{27}$.

As for spasticity, as noted above, only the extensors muscles knee was evaluated by the MAS. This muscle usually presents an abnormal hyperactivity, which manifests, especially in the balance phase, during acceleration and intermediate balance of gait ${ }^{31}$. Spasticity is considered a common manifestation that results from abnormal neuroplasticity and intrinsic changes in the affected muscles ${ }^{32}$. Wissel et al. ${ }^{33}$ pointed out that the presence of spasticity is associated with complaints of pain, greater impairment of muscle strength, and lower levels of functional independence. Our study corroborates these findings and indicates that this combination of higher degrees of spasticity with higher strength deficit is indicators of worse performance.

Another parameter that is strong and significantly related to the performance in GST is functional mobility, which in this study was evaluated by TUGT. Persson et $a l .^{34}$ indicated that the TUGT is a sensitive test to detect changes in functional mobility in this special population, through time. This test is practical, fast, and low cost and has been widely used, especially in the elderly and hemiparetic patients evaluation. It allows estimating performance in several daily tasks such as getting up from a chair, walking, turning on one's own axis, and sitting down ${ }^{35}$.

\section{Conclusion}

The study shows that there is a strong and significant relationship between GS and the degree of paresis, spasticity, and functional mobility.

The combination of an important motor deficit ex pressed by greater asymmetry of strength muscle between the paretic and non-paretic sides, and a greater degree of spasticity indicates worse gait performance.

We must improve evaluation of strength and tonus muscle to develop programs that emphasize increased strength and management of spasticity. A careful evaluation, followed by an adequate intervention, will certainly bring benefits to the locomotion these patients, and this is crucial to achieve this goal so desired by patients seeking a rehabilitation service.
These results should be viewed with caution, as the small number of patients evaluated is a limitation. New studies should be carried out with a larger number of participants, as well as the analysis of other variables not controlled here.

\section{Funding}

This study was partly financed by the Coordenação de Aperfeiçoamento de Pessoal de Nível Superior Brasil (CAPES) - Finance Code 001.

\section{Conflicts of interest}

None to declare.

\section{Ethical disclosures}

Protection of human and animal subjects. The authors declare that the procedures followed were in accordance with the regulations of the relevant clinical research ethics committee and with those of the Code of Ethics of the World Medical Association (Declaration of Helsinki).

Confidentiality of data. The authors declare that they have followed the protocols of their work center on the publication of patient data.

Right to privacy and informed consent. The authors have obtained the written informed consent of the patients or subjects mentioned in the article. The corresponding author is in possession of this document.

\section{References}

1. Araújo JP, Darcis JV, Tomas AC, Mello WA. Mortality trend due to cerebrovascular accident in the city of Maringá, Paraná between the years of 2005 to 2015. Int J Cardiovasc Sci. 2018;31:56-62.

2. Flansbjer UB, Downham D, Lexell J. Knee muscle strength, gait performance, and perceived participation after stroke. Arch Phys Med Rehabil. 2006;87:974-80.

3. Lopes PG, Lopes JA, Brito CM, Alfieri FM, Rizzo Battistella L. Relationships of balance, gait performance, and functional outcome in chronic stroke patients: a comparison of left and right lesions. Biomed Res Int. 2015;2015:716042.

4. Fritz S, Lusardi M. White paper: "walking speed: the sixth vital sign". J Geriatr Phys Ther. 2009;32:46-9.

5. Peel NM, Kuys SS, Klein K. Gait speed as a measure in geriatric assessment in clinical settings: a systematic review. J Gerontol A Biol Sci Med Sci. 2013;68:39-46.

6. Schmid A, Duncan PW, Studenski S, Lai SM, Richards L, Perera S, et al. Improvements in speed-based gait classifications are meaningful. Stroke. 2007:38:2096-100.

7. Thomas JR, Nelson JK, Silverman SJ. Métodos de Pesquisa em Atividade Física. $6^{\text {th }}$ ed. Porto Alegre: Artmed; 2012.

8. Bertolucci PH, Brucki SM, Campacci SR, Juliano Y. O mini-exame do estado mental em uma população geral: impacto da escolaridade. Arq Neuropsiquiatr. 1994;52:1-7.

9. World Health Organization. WHO Steps Stroke Manual: the WHO Step Wise Approach to Stroke Surveillance. Geneva: World Health Organization; 2006

10. Fugl-Meyer AR, Jääskö L, Leyman I, Olsson S, Steglind S. The poststroke hemiplegic patient. 1. a method for evaluation of physical performance. Scand J Rehabil Med. 1975;7:13-31. 
11. Heidari M, Abootalebi C, Hosseini SA. Validity of modified ash worth scale as a measure of wrist spasticity in stroke patients. Iran Rehabil J. 2011;9:26-30.

12. Podsiadlo D, Richardson S. The timed "Up and Go": a test of basic functional mobility for frail elderly persons. J Am Geriatr Soc. 1991;39:142-8.

13. Soares AV, Matos FM, Laus LH, Suzuki S. Estudo comparativo sobre a propensão de quedas em idosos institucionalizados e não institucionalizados através do nível de mobilidade funcional. Fisioter Bras. 2003;4:12-6.

14. Hafsteinsdóttir TB, Rensink M, Schuurmans M. Clinimetric properties of the timed up and go test for patients with stroke: a systematic review. Top Stroke Rehabil. 2014;21:197-210.

15. Chen CL, Chang KJ, Wu PY, Chi CH, Chang ST, Cheng YY. Comparison of the effects between isokinetic and isotonic strength training in subacute stroke patients. J Stroke Cerebrovasc Dis. 2015;24:1317-23.

16. Huh JS, Lee YS, Kim CH, Min YS, Kang MG, Jung TD. Effects of balance control training on functional outcomes in subacute hemiparetic stroke patients. Ann Rehabil Med. 2015;39:995-1001.

17. Isho T, Usuda S. Association of trunk control with mobility performance and accelerometry-based gait characteristics in hemiparetic patients with subacute stroke. Gait Posture. 2016;44:89-93.

18. Faria CD, Teixeira-Salmela LF, Silva EB, Nadeau S. Expanded timed up and go test with subjects with stroke: reliability and comparisons with matched healthy controls. Arch Phys Med Rehabil. 2012;93:1034-8.

19. Piva SR, Fitzgerald GK, Irrgang JJ, Bouzubar F, Starz TW. Get up and go test in patients with knee osteoarthritis. Arch Phys Med Rehabil. 2004;85:284-9.

20. Martins JC, Aguiar LT, Lara EM, Moura JB, Souza LA, Teixeira-Salmela LF et al. Assessment of the strength of the lower limb muscles in subjects with stroke with portable dynamometry: a literature review. Fisioter mov. 2016;29:193-208

21. Souza LA, Martins JC, Teixeira-Salmela LF, Lara EM, Moura JB Aguiar LT, et al. Validity and reliability of the modified sphygmomanometer test to assess strength of the lower limbs and trunk muscles after stroke. J Rehabil Med. 2014;46:620-8.

22. Cooper A, Alghamdi GA, Alghamdi MA, Altowaijri A, Richardson S. The relationship of lower limb muscle strength and knee joint hyperextension during the stance phase of gait in hemiparetic stroke patients. Physiother Res Int. 2012;17:150-6.
23. Akbari $\mathrm{A}$, Karimi $\mathrm{H}$. The effect of strengthening exercises on exaggerated muscle tonicity in chronic hemiparesis following stroke. J Med Sci. 2006;6:382-8.

24. Correa CS, da Silva BG, Alberton CL, Wilhelm EN, Moraes DA, Lima CS, et al. Análise da força isométrica máxima e do sinal de EMG em exercícios para os membros inferiores. Rev Bras Cineantropom Desempenho Hum. 2011;13:429-5.

25. Kiyama R, Fukudome K, Hiyoshi T, Umemoto A, Yoshimoto Y, Maeda T. The loss of dexterity in the bilateral lower extremities in patients with stroke. J Appl Biomech. 2011;27:122-9.

26. Iwabe C, Diz MA, Barudy DP. Análise cinemática da marcha em indivíduos com acidente vascular encefálico. Rev Neurociênc. 2008;16:292-6.

27. Signal NE. Strength training after stroke: rationale, evidence and potential implementation barriers for physiotherapists. N Z J Physiother. 2014:42:101-7.

28. Beavers KM, Beavers DP, Houston DK, Harris TB, Hue TF, Koster A, et al. Associations between body composition and gait-speed decline: results from the health, aging, and body composition study. Am J Clin Nutr. 2013:97:552-60.

29. Sheffler LR, Bailey SN, Gunzler D, Chae J. Effect of body mass index on hemiparetic gait. PM R. 2014;6:908-13.

30. Hyun CW, Han EY, Im SH, Choi JC, Kim BR, Yoon HM, et al. Hemiparetic knee extensor strength and balance function are predictors of ambulatory function in subacute stroke patients. Ann Rehabil Med. 2015;39:577-85.

31. Boudarham J, Roche N, Pradon D, Delouf E, Bensmail D, Zory R. Effects of quadriceps muscle fatigue on stiff-knee gait in patients with hemiparesis. PLoS One. 2014;9:e94138.

32. Li S, Francisco GE. New insights into the pathophysiology of post-stroke spasticity. Front Hum Neurosci. 2015;9:192.

33. Wissel J, Schelosky LD, Scott J, Christe W, Faiss JH, Mueller J. Early development of spasticity following stroke: a prospective, observational trial. J Neurol. 2010;257:1067-72.

34. Persson CU, Danielsson A, Sunnerhagen KS, Grimby-Ekman A, Hansson PO. Timed up and go as a measure for longitudinal change in mobility after stroke - postural stroke study in gothenburg (POSTGOT). J Neuroeng Rehabil. 2014;11:83.

35. Soares AV, Marcelino E, Borges NG Jr., Domenech SC, Loch MS, Sagawa Y Jr. Relação entre dinapenia, sarcopenia e mobilidade funcional em idosos frágeis institucionalizados. Medicina (Ribeirão Preto). 2016:49:195-201. 